\title{
Anaerobic oxidation of methane in grassland soils used for cattle husbandry
}

\author{
A. Bannert ${ }^{1}$, C. Bogen ${ }^{2}$, J. Esperschütz ${ }^{2}$, A. Koubová, ${ }^{3,4}$, F. Buegger ${ }^{5}$, D. Fischer ${ }^{1}$, V. Radl ${ }^{1}$, R. Fu $\beta^{6}$, \\ A. Chroňáková ${ }^{3,4}$, D. Elhottová ${ }^{3}$, M. Š Emek $^{3,4}$, and M. Schloter ${ }^{1}$ \\ ${ }^{1}$ Research Unit for Environmental Genomics, Helmholtz Zentrum München - German Research Center for Environmental \\ Health, Ingolstädter Landstraße 1, Neuherberg, 85764, Germany \\ ${ }^{2}$ Chair of Soil Ecology, Technische Universität München, Ingolstädter Landstraße 1, Neuherberg, 85764, Germany \\ ${ }^{3}$ Institute of Soil Biology, Biology Centre AS CR, v. v. i., Na Sádkách 7, 37005 České Budějovice, Czech Republic \\ ${ }^{4}$ Faculty of Science, University of South Bohemia, Branišovská 31, 37005 České Budějovice, Czech Republic \\ ${ }^{5}$ Institute of Soil Ecology, Helmholtz Zentrum München - German Research Center for Environmental Health, Ingolstädter \\ Landstraße 1, Neuherberg, 85764, Germany \\ ${ }^{6}$ Institute of Agricultural Climate Research, Johann Heinrich von Thünen Institute, 38116 Braunschweig, Germany
}

Correspondence to: A. Bannert (andrea.bannert@helmholtz-muenchen.de)

Received: 22 March 2012 - Published in Biogeosciences Discuss.: 24 April 2012

Revised: 21 August 2012 - Accepted: 28 August 2012 - Published: 10 October 2012

\begin{abstract}
While the importance of anaerobic methane oxidation has been reported for marine ecosystems, the role of this process in soils is still questionable. Grasslands used as pastures for cattle overwintering show an increase in anaerobic soil micro-sites caused by animal treading and excrement deposition. Therefore, anaerobic potential methane oxidation activity of severely impacted soil from a cattle winter pasture was investigated in an incubation experiment under anaerobic conditions using ${ }^{13} \mathrm{C}$-labelled methane. We were able to detect a high microbial activity utilizing $\mathrm{CH}_{4}$ as nutrient source shown by the respiration of ${ }^{13} \mathrm{CO}_{2}$. Measurements of possible terminal electron acceptors for anaerobic oxidation of methane were carried out. Soil sulfate concentrations were too low to explain the oxidation of the amount of methane added, but enough nitrate and iron(III) were detected. However, only nitrate was consumed during the experiment. ${ }^{13} \mathrm{C}$-PLFA analyses clearly showed the utilization of $\mathrm{CH}_{4}$ as nutrient source mainly by organisms harbouring 16 : $1 \omega 7$ PLFAs. These lipids were also found as most ${ }^{13} \mathrm{C}$ enriched fatty acids by Raghoebarsing et al. (2006) after addition of ${ }^{13} \mathrm{CH}_{4}$ to an enrichment culture coupling denitrification of nitrate to anaerobic oxidation of methane. This might be an indication for anaerobic oxidation of methane by relatives of "Candidatus Methylomirabilis oxyfera" in the investigated grassland soil under the conditions of the incubation experiment.
\end{abstract}

\section{Introduction}

Methane is well known as a carbon and energy source for a specific group of methanotrophic microorganisms under aerobic conditions (Mancinelli, 1995). Today, however, a new role of methane has attracted the focus of research: the importance for the growth of microorganisms under anaerobic conditions (Thauer and Shima, 2008). Though the anaerobic oxidation of methane (AOM) was thought to be biochemically impossible for a long time and thus absent in nature (reviewed by Strous and Jetten, 2004), there has been recent evidence that this microbial mediated process could be a major factor in global carbon cycling (Shima and Thauer, 2005; Strous and Jetten, 2004; Valentine and Reeburgh, 2000; Smemo and Yavitt, 2011).

Different terminal electron acceptors have been described so far for AOM (Thauer and Shima, 2008; Smemo and Yavitt, 2011). Studies on marine sediments indicated the use of sulphate by a consortium of anaerobic methanotrophic archaea (so-called ANME) and sulphate-reducing bacteria (Strous and Jetten, 2004; Valentine and Reeburgh, 2000; Boetius et al., 2000; Hinrichs et al., 1999). This process is considered to consume most of the methane produced in marine sediments (Valentine, 2002). The reaction mechanism, its biochemistry and physiology are still under discussion and apparently involve reverse methanogenesis (Thauer and Shima, 2008). 
The second electron acceptor described so far is nitrate/nitrite (Ettwig et al., 2009, 2010; Raghoebarsing et al., 2006). In contrast to the microbial consortium using sulphate as electron acceptor under anaerobic conditions, which requires the close interaction of bacteria and archaea, it has been postulated that AOM in the presence of nitrate/nitrite can be catalyzed by one single bacterium which belongs to the so far uncultured phylum NC10 (Ettwig et al., 2009; Thauer and Shima, 2008). One of the very few studies focusing on anaerobic oxidation of methane investigates isotope fractionation factors for carbon and hydrogen during methane oxidation by an enrichment culture of "Candidatus M. oxyfera" (Rasigraf et al., 2012). Values were similar to those found for aerobic and other anaerobic methanotrophs. The results show that biological methane oxidation has a narrow range of fractionation factors for carbon and hydrogen irrespective of the underlying biochemical mechanism.

AOM coupled to nitrate reduction has been reported for various nutrient-rich aquatic habitats, including contaminated groundwater (Smith et al., 1991), sewage sludge (IslasLima et al., 2004), eutrophic canals and ditches (Ettwig et al., 2009), but also sediments of an oligotrophic freshwater lake (Deutzmann and Schink, 2011). Next to these aquatic habitats, the AOM was also recently described in drained peat and automorphic sod-podzol soils. The addition of oxidized compounds (e.g. nitrate) had a stimulatory effect on methane consumption in these soils (Pozdnyakov et al., 2011) under anaerobic conditions. The latter finding indicates that AOM might not be limited to aquatic systems only, but might also occur in other (soil) ecosystems, especially in soils with prevailing or frequently occurring larger anaerobic compartments, e.g. submerged soils, subsoils or mechanically compacted soils.

Pasture sites used for cattle overwintering in Central Europe are highly influenced by the animals. Compared to ordinary pastures, which are used for grazing during summer time, a much higher number of animals are present on a small area for a relatively long period. This causes a reduction in soil aeration through soil compaction (Menneer et al., 2005). The presence of animals is accompanied by a high input of organic material through excrements which consequently stimulates microbial metabolism, increases oxygen demand and supports the occurrence of anoxic (micro)sites in the soil (Šimek et al., 2006). Not surprisingly, Radl et al. (2007) could therefore demonstrate high abundance of methanogens in these soils during winter time as well as high methane production rates. Due to the prevailing anaerobic conditions and the high concentrations of ammonia from excrements in the soil, abundances of aerobic methane oxidizers carrying the pmoA gene were low (Radl et al., 2007). Nevertheless, in-situ methane oxidation rates in those soils were high; therefore, it has been postulated that AOM might play an important role in the investigated site for methane consumption.

To test this hypothesis, we incubated severely impacted soils from a cattle winter pasture under anaerobic conditions using ${ }^{13} \mathrm{C}$-labelled methane. Soil from the same area, which was not used for cattle overwintering, served as control. Measurements of gases were performed using isotope ratio mass spectrometry (IRMS). Subsequent phospholipid fatty acid (PLFA) analysis provided insights into the microorganisms possibly involved in anaerobic methane oxidation.

\section{Materials and methods}

\subsection{Site description and soil sampling}

Soil samples were taken from a cattle-grazed farmland in Borová, South Bohemia, Czech Republic $\left(48^{\circ} 52^{\prime} \mathrm{N}\right.$, $14^{\circ} 13^{\prime} \mathrm{E}$ ), characterized by a mean annual temperature of $7^{\circ} \mathrm{C}$ and a sum of precipitation of $650 \mathrm{~mm}$. The soil is characterized as sandy loam and classified as Cambisol containing 60-80\% sand, $14-32 \%$ silt and 6-14\% clay (for other details on the site and soil, see Hynšt et al., 2007 and Radl et al., 2007).

For the present study we sampled soils in April 2009, at the end of the overwintering period 2008/2009. Soils from two sites were sampled: a severely impacted site (SI) located in close proximity to the stables and being the overwintering area for the cattle, and a control plot (CO) which had not been used for cattle grazing and overwintering since 1999. The control had an intact plant cover consisting of a perennial mixture of grasses and dicotyledonous plants such as clovers (Jirout et al., 2009), while the plant cover of the severely impacted site was completely destroyed at the time of sampling, exposing the surface soil. Five independent field replicates ( $200 \mathrm{~g}$ each) from each site were randomly taken with a soil auger from $0-20 \mathrm{~cm}$ depth pooled for further analysis to reduce field heterogeneity, and stored at $4{ }^{\circ} \mathrm{C}$ for 2 weeks before the incubation experiment started.

\section{$2.2 \quad{ }^{13} \mathrm{C}$ labelling experiment}

To generate anaerobic conditions, $10 \mathrm{~g}$ of soil were filled into a serum bottle $(100 \mathrm{ml})$, followed by the adjustment of the water content to $100 \%$ of the maximum water holding capacity using distilled water. Overall 13 bottles of SI and CO soil were prepared. Finally, the bottles were sealed with a butyl rubber septum. To ensure the absence of oxygen also in soil pores, bottles were purged with nitrogen $\left(\mathrm{N}_{2}, 5.0\right.$ grade $)$ twice within $25 \mathrm{~h}$. At each time the added nitrogen replaced the headspace atmosphere two times. Finally, $500 \mu \mathrm{l}$ of labelled methane $\left(20.2 \%{ }^{13} \mathrm{C}\right.$-enriched) were injected into 8 serum bottles with SI soil $\left(\mathrm{SI}_{\mathrm{CH}_{4}}\right)$ and 8 bottles with $\mathrm{CO}$ soil $\left(\mathrm{CO}_{\mathrm{CH}_{4}}\right)$. As a control, 5 replicates of SI and 5 replicates of $\mathrm{CO}$ soil were left without methane amendments (SI, CO).

The samples were subsequently maintained at a constant temperature of $14^{\circ} \mathrm{C}$ on a CombiPAL Autosampler (CTC, Zwingen, Switzerland) for 7 days.

During the incubation, $\mathrm{CO}_{2}$ and $\mathrm{CH}_{4}$ concentrations, as well as their corresponding ${ }^{13} \mathrm{C}:{ }^{12} \mathrm{C}$ ratios in 
headspaces, were determined on-line using a gas chromatography / isotope ratio mass spectrometer system (GC/IRMS; Finnigan MAT, delta plus, Germany). Part of the assembly was a modified PreCon Interface (Finnigan MAT) which enables also measurements of high $\mathrm{CO}_{2}$ and $\mathrm{CH}_{4}$ concentrations by varying the injection volumes. The fraction of $\mathrm{CO}_{2}$ originating from oxidized $\mathrm{CH}_{4}\left(f_{\mathrm{CH}_{4}}\right)$ was calculated from

$f_{\mathrm{CH}_{4}}=\frac{{ }^{13} \mathrm{C}_{\mathrm{emission}} \text { treatment }-{ }^{13} \mathrm{C}_{\mathrm{emission} \mathrm{control}}}{{ }^{13} \mathrm{C}_{\mathrm{CH}_{4}}-{ }^{13} \mathrm{C}_{\mathrm{emission} \mathrm{control}}}$

where ${ }^{13} \mathrm{C}_{\mathrm{CH}_{4}}$ is the ${ }^{13} \mathrm{C}$ amount of the added $\mathrm{CH}_{4}$ and ${ }^{13} \mathrm{C}_{\text {emission }}$ is the ${ }^{13} \mathrm{C}$ amount in the $\mathrm{CO}_{2}$ emitted during a certain time period. ${ }^{13} \mathrm{C}_{\text {emission was calculated as follows: }}$

${ }^{13} \mathrm{C}_{\text {emission }}=\frac{\mathrm{C}_{n / n+1} \times{ }^{13} \mathrm{C}_{n / n+1}-\mathrm{C}_{n} \times{ }^{13} \mathrm{C}_{n}}{\mathrm{C}_{n / n+1}-\mathrm{C}_{n}}$

in which $\mathrm{C}_{n / n+1}$ are the $\mathrm{CO}_{2}$ concentration at points in time $n / n+1$ and ${ }^{13} \mathrm{C}_{n / n+1}$ are the ${ }^{13} \mathrm{C}$ amounts at points in time $n / n+1$.

At the end of the incubation experiment, soil subsamples for PLFA analysis were stored at $-80^{\circ} \mathrm{C}$, while subsamples subjected to measurements of microbial biomass as well as abiotic soil properties were analyzed immediately.

\subsection{Soil physical and chemical properties}

Soils from both the incubation experiment (SI, CO, $\mathrm{SI}_{\mathrm{CH}_{4}}$, $\mathrm{CO}_{\mathrm{CH}_{4}}$ ) as well as from the time before the incubation experiment started $\left(\mathrm{SI}_{T 0}, \mathrm{CO}_{T 0}\right)$ were extracted with $0.01 \mathrm{M} \mathrm{CaCl}_{2}$ at a soil-to-liquid ratio of $1: 2$. For the determination of water extractable organic carbon (WEOC) and nitrogen (WEON), an analyzer DIMATOC 100 (DIMATEC Analysentechnik GmbH, Essen, Germany) was used. Determination of ammonium $\left(\mathrm{NH}_{4}^{+}-\mathrm{N}\right)$ and nitrate $\left(\mathrm{NO}_{3}^{-}-\mathrm{N}\right)$ soil concentrations was done by continuous flow analysis with a photometric autoanalyzer (CFA-SAN Plus/Skalar Analytik, Germany). The content of reducible iron [Fe(III)] was determined using the hydroxylamine extraction method and spectrophotometric analysis (Lovley and Phillips, 1987). Sulphate was measured with the NANOCOLOR Sulphate 200 kit (Macherey-Nagel, Germany) at a soil-to-liquid ratio of $1: 9$.

Microbial biomass was determined by the chloroformfumigation extraction method (Vance et al., 1987) with $1 \mathrm{~g}$ of soil in $16 \mathrm{ml} 0.5 \mathrm{M} \mathrm{K}_{2} \mathrm{SO}_{4}$ solution. For the determination of microbial biomass carbon $\left(\mathrm{C}_{\mathrm{mic}}\right)$, aliquots of the soils were fumigated with chloroform for $24 \mathrm{~h}$ prior to $\mathrm{CaCl}_{2}$ extraction (Jörgensen and Brookes, 1991). C concentration and ${ }^{13} \mathrm{C}$ abundance were measured by a liquid chromatography/isotope ratio mass spectrometer system (LC/IRMS) (LC IsoLink coupled with MAT 253, both Thermo Finnigan, Bremen) as described by Krummen et al. (2004) and Marx et al. (2007). ${ }^{13} \mathrm{C}$ abundance was calculated by allegation alternate (Marx et al., 2007).

\subsection{Phospholipid fatty acid analysis}

Phospholipid fatty acid extraction was performed according to Zelles et al. (1995). Replicates from incubated SI soils with as well as respectively without methane $\left(\mathrm{SI}_{\mathrm{CH}_{4}}, \mathrm{SI}\right)$ were pooled and an equivalent of $10 \mathrm{~g}$ of dry soil were extracted with a mixture of $125 \mathrm{ml}$ methanol, $63 \mathrm{ml}$ chloroform and $50 \mathrm{ml}$ phosphate buffer $(0.05 \mathrm{M}, \mathrm{pH} 7)$.

After $2 \mathrm{~h}$ of horizontal shaking, $63 \mathrm{ml}$ water and $63 \mathrm{ml}$ chloroform were added to promote phase separation. After $24 \mathrm{~h}$ the water phase was removed and discarded. The total lipid extract was separated into neutral lipids, glycolipids and phospholipids on a silica-bonded phase column (SPE-SI $2 \mathrm{~g} / 12 \mathrm{ml}$; Bond Elut, Analytical Chem International, CA, USA). The phospholipid fraction was further separated into saturated (SATFA), monounsaturated (MUFA), polyunsaturated (PUFA), non-ester-linked unsubstituted (NEL-UNSFA) and hydroxy-substituted (NEL-UNOH) fatty acids (see Zelles et al., 1995 and Zelles, 1999 for details). PLFAs were analyzed as fatty acid methyl esters (FAME) on a gas chromatograph / mass spectrometry system (5973 MSD GC / MS Agilent Technologies, Palo Alto, USA) linked via a combustion unit to an isotope ratio mass spectrometer (GC/MS-CIRMS, DeltaPlus ${ }^{\text {Advantage }}$, Thermo Finnigan, Bremen, Germany). Separation and detection of FAME was performed via GC/MS, while the isotopic composition of fatty acids was detected after combustion (GC Combustion III, Thermo Finnigan, Bremen, Germany) in the IRMS. Columns and temperature programs were used according to Esperschuetz et al. (2009). The lipid fraction of monounsaturated fatty acid was measured underivatized to obtain a correct isotopic signal. After the first measurement, the sample was subjected to a DMDS-derivatization to identify the position of the double bond. The mass spectra of the individual FAMEs were identified by comparison with established fatty acid libraries (Solvit, Luzern, Switzerland) using MSD ChemStation (Version D.02.00.237).

Standard nomenclature for PLFA was used according to Frostegard et al. (1993): the number before the colon represents the number of $\mathrm{C}$-atoms; the number after the colon gives the number of double bonds and their location from the aliphatic end $(\omega)$. The prefixes "cy-", "iso-" and "ant-" indicate cyclopropyl-groups, and iso- and anteiso-branching, respectively. Saturated straight-chained fatty acids were indicated by " $n$ ". The "br" and the number before a fatty acid indicate methyl-branching at the individual C-atom. The prefixes $\alpha$ and $\beta$ indicate that the $\mathrm{OH}$ groups of an unsaponifiable $\mathrm{OH}$ fatty acid are located at positions 2 and 3, respectively, while numbers preceded by $\omega$ indicate the position of $\mathrm{OH}$ groups from the aliphatic end. Non-ester-linked (unsaponifiable) fatty acids were indicated by NEL (Zelles, 1999). 


\subsection{Statistical analysis}

Prior to analysis, data were tested for normal distribution by $Q-Q$ plots and the Kolmogorov-Smirnov test. Homogeneity of variances was checked by Levene's test. Soil chemical parameters were subjected to analysis of variance (two-factor ANOVA). Means were considered significantly different at $P \leq 0.05$. A linear mixed-effects model was fit to time series of $\mathrm{CO}_{2}$ concentration originating from methane (Fig. 1). The model considered the fixed effects soil, time, and their interaction; repeated measures were considered as a random effect. Temporal autocorrelation of residuals was not significant and, consequently, was not modelled. All statistical calculations were carried out using SPSS software version 13.0 (SPSS Inc, Chicago, IL), except the linear mixed-effects model for which R 2.14.1 (www.R-project.org) with library nlme was used.

\section{Results}

\subsection{Consumption of methane}

In contrast to $\mathrm{CO}$, SI showed a significant consumption of the added methane and production of carbon dioxide under anaerobic conditions (Fig. 1). Whereas in $\mathrm{CO}$ a maximum of $0.83 \%$ of $\mathrm{C}$ incorporation after 6.4 days of methane addition was measured, the incorporation of carbon derived from $\mathrm{CH}_{4}$ into $\mathrm{CO}_{2}$ in SI samples was observed already after 2.8 days $(2.4 \%)$. The incorporation reached the maximum of $8.5 \%$ after 4.4 days and then declined to $4.0 \%$ after 6.2 days. The high standard deviations of mean $\mathrm{C}$ incorporated from $\mathrm{CH}_{4}$ into $\mathrm{CO}_{2}$ might be related to the fact that methane consumption in some replicates started later than in others.

Concentration increase of $\mathrm{CO}_{2}$ originating from $\mathrm{CH}_{4}$, measured by ${ }^{13} \mathrm{C}$ incorporation, with time was significantly $(p<0.0001)$ higher for SI soil than for CO soil. In total, the percentage of $\mathrm{C}$ in $\mathrm{CO}_{2}$ originating from $\mathrm{CH}_{4}$ oxidation was $22 \%$ for the SI soil and $3.7 \%$ for the $\mathrm{CO}$ soil. The methane added to SI soil samples incubated under anaerobic conditions was almost completely consumed $(91.3 \%)$. In the control treatments of SI soil without methane addition, the share of $\mathrm{CH}_{4}-\mathrm{C}$ incorporated into $\mathrm{CO}_{2}$ was below $0.03 \%$ over the whole experimental period

\subsection{Soil chemical properties}

Content of water-extractable organic carbon (WEOC) was about ten times higher in SI soils compared to CO soils and was neither affected by the addition of methane nor by the incubation (Table 1). Content of water-extractable organic nitrogen (WEON) significantly decreased in SI soil during anaerobic incubation, from 13 to 8.2 and $9.7 \mu \mathrm{g} \mathrm{N} \mathrm{g}^{-1} \mathrm{dw}$ in the treatment without methane and with methane, respectively. Nitrate concentrations in SI and CO soils were under or near the detection limit in the anaerobic treat-

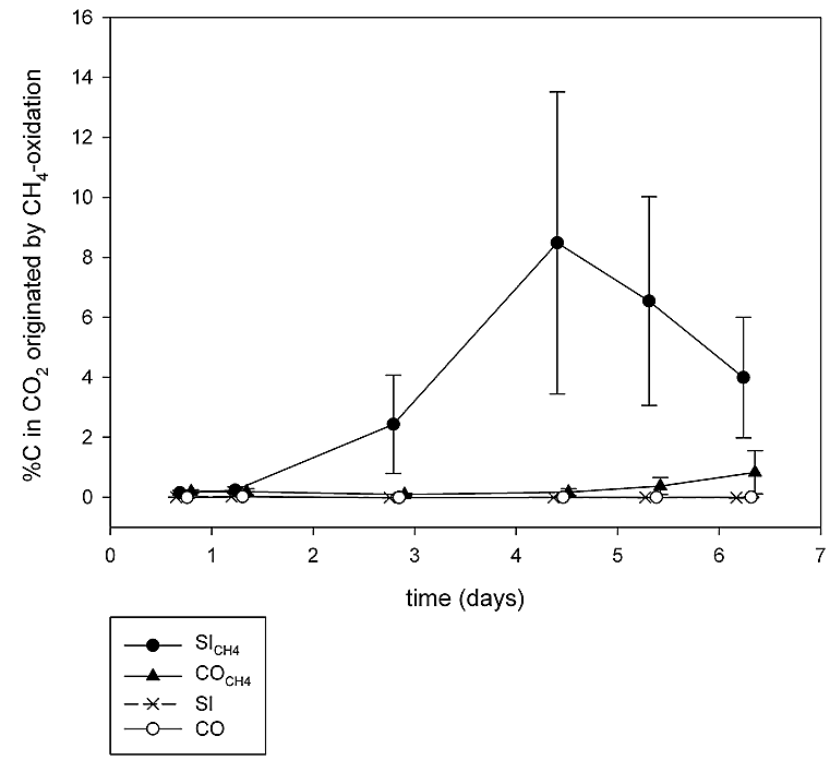

Fig. 1. Percentage of $\mathrm{C}$ incorporated into $\mathrm{CO}_{2}$ originated from $\mathrm{CH}_{4}$ at different time points $\left(f_{\mathrm{CH}_{4}} \times 100 \%\right)$ for the severely impacted soil with methane $\left(\mathrm{SI}_{\mathrm{CH}_{4}}\right)$, control soil with methane $\left(\mathrm{CO}_{\mathrm{CH}_{4}}\right)$ and treatments without methane (SI, CO). Results are presented as means \pm standard deviation $\left(n=8\right.$ for $\mathrm{SI}_{\mathrm{CH}_{4}}$ and $\mathrm{CO}_{\mathrm{CH}_{4}} ; n=5$ for SI and CO).

ments; however, values in the original soils were significantly higher and accounted for $23 \mu \mathrm{g} \mathrm{NO}_{3}^{-}-\mathrm{Ng}^{-1}$ of soil in SI and $9.0 \mu \mathrm{g} \mathrm{NO}_{3}^{-}-\mathrm{N} \mathrm{g}^{-1}$ in $\mathrm{CO}$. Ammonium concentration increased significantly in SI soil samples from $1.0 \mu \mathrm{g} \mathrm{N} \mathrm{g}^{-1} \mathrm{dw}$ before anaerobic incubation to 13 and $12 \mu \mathrm{g} \mathrm{Ng}^{-1} \mathrm{dw}$ in treatments without and with methane amendment. Ammonium concentration in $\mathrm{CO}$ soils, however, did not change during the incubation (Table 1). Reducible iron was significantly higher in CO than in SI soils, but no significant difference between the treatments was found. The content of sulphate was below the detection limit $\left(0.13 \mathrm{mg} \mathrm{S} \mathrm{g}^{-1} \mathrm{dw}\right)$ in all soil samples.

\subsection{Microbial biomass and microbial community structure}

Microbial biomass $\left(\mathrm{C}_{\mathrm{mic}}\right)$ was 3.7 times higher in SI soil compared to $\mathrm{CO}$ soil (Table 1). After methane addition and anaerobic incubation, $\mathrm{C}_{\text {mic }}$ was significantly enriched in ${ }^{13} \mathrm{C}$ (+19\%o VPDB) compared to the treatment without methane $(-28 \%$ VPDB) in SI soil, while no enrichment was found in soil $\mathrm{CO}$ (Fig. 2).

In total, 69 different PLFAs were detected in $\mathrm{SI}_{\mathrm{CH}_{4}}$ and SI treatments. Since $\mathrm{CH}_{4}$ was enriched with ${ }^{13} \mathrm{C}$, PLFAs of methane-oxidizing microbial communities showed increased $\delta^{13} \mathrm{C}$ values compared to the controls. In Fig. 3, a ranking is given of PLFAs with high ${ }^{13} \mathrm{C}$ incorporation. Highest ${ }^{13} \mathrm{C}$ enrichment was detected in monounsaturated 
Table 1. Soil characteristics of SI and $\mathrm{CO}$ before the incubation experiment started $\left(\mathrm{CO}_{T 0}, \mathrm{SI}_{T 0}\right)$ and after major anaerobic experiment without $(\mathrm{CO}, \mathrm{SI})$ and with methane $\left(\mathrm{CO}_{\mathrm{CH}_{4}}, \mathrm{SI}_{\mathrm{CH}_{4}}\right)$. Different parameters were measured: $\mathrm{pH}$ value $\left(\mathrm{CaCl}_{2}\right)$, water extractable organic carbon (WEOC) and nitrogen (WEON), nitrate and ammonium concentrations, reducible iron [Fe(III)], microbial biomass $\left(\mathrm{C}_{\mathrm{mic}}\right)$ and $\delta{ }^{13} \mathrm{C}_{\mathrm{mic}}$. Means and standard deviations, significant differences among treatments at $p<0.05$ are indicated by different letters $(\mathrm{a}, \mathrm{b}, \mathrm{c})$.

\begin{tabular}{|c|c|c|c|c|c|c|}
\hline Soil parameters & $\mathrm{CO}_{T 0}$ & $\mathrm{CO}$ & $\mathrm{CO}_{\mathrm{CH}_{4}}$ & $\mathrm{SI}_{T 0}$ & SI & $\mathrm{SI}_{\mathrm{CH}_{4}}$ \\
\hline pH & 5.3 & 5.8 & 5.8 & 7.3 & 7.1 & 7.1 \\
\hline $\begin{array}{l}\text { WEOC } \\
\left(\mu \mathrm{gg}^{-1} \mathrm{dw}\right)\end{array}$ & $\begin{array}{r}27 a \\
(2.6)\end{array}$ & $\begin{array}{r}23 a \\
(8.2)\end{array}$ & $\begin{array}{r}23 a \\
(4.6)\end{array}$ & $\begin{array}{r}250 b \\
(39)\end{array}$ & $\begin{array}{r}220 b \\
(13)\end{array}$ & $\begin{array}{r}230 b \\
(23)\end{array}$ \\
\hline $\begin{array}{l}\text { WEON } \\
\left(\mu \mathrm{g} \mathrm{g}^{-1} \mathrm{dw}\right)\end{array}$ & $\begin{array}{r}2.6 a \\
(0.89)\end{array}$ & b.d.l. ${ }^{\mathrm{a}}$ & $\begin{array}{l}0.35 b \\
(0.63)\end{array}$ & $\begin{array}{r}13 c \\
(1.2)\end{array}$ & $\begin{array}{r}8.2 d \\
(0.67)\end{array}$ & $\begin{array}{r}9.7 e \\
(0.55)\end{array}$ \\
\hline $\begin{array}{l}\text { Nitrate } \\
\left(\mu \mathrm{g} \mathrm{Ng}^{-1} \mathrm{dw}\right)\end{array}$ & $\begin{array}{l}9.0 a \\
(0.0)\end{array}$ & $\begin{array}{l}0.25 b \\
(0.43)\end{array}$ & b.d.l. ${ }^{\mathrm{a}}$ & $\begin{array}{r}23 c \\
(2.1)\end{array}$ & b.d.l. & b.d.l. \\
\hline $\begin{array}{l}\text { Ammonium } \\
\left(\mu \mathrm{g} \mathrm{Ng}^{-1} \mathrm{dw}\right)\end{array}$ & $\begin{array}{r}1.2 a \\
(0.24)\end{array}$ & $\begin{array}{r}2.4 a \\
(0.56)\end{array}$ & $\begin{array}{r}1.7 a \\
(0.38)\end{array}$ & $\begin{array}{r}1.0 a \\
(0.82)\end{array}$ & $\begin{array}{r}13 b \\
(1.5)\end{array}$ & $\begin{array}{r}12 b \\
(1.5)\end{array}$ \\
\hline $\begin{array}{l}\text { Iron } \\
\left(\mu \mathrm{g} \mathrm{g}^{-1} \mathrm{dw}\right)\end{array}$ & $\begin{array}{r}140 a \\
(15)\end{array}$ & $\begin{array}{r}130 a \\
(8.6)\end{array}$ & $\begin{array}{r}120 a \\
(21)\end{array}$ & $\begin{array}{l}83 b \\
(20)\end{array}$ & $\begin{array}{r}69 b \\
(7.7)\end{array}$ & $\begin{array}{r}63 b \\
(6.6)\end{array}$ \\
\hline $\begin{array}{l}\mathrm{C}_{\mathrm{mic}} \\
\left(\mu \mathrm{gg}^{-1} \mathrm{dw}\right)\end{array}$ & $\begin{array}{l}150 a \\
(16)\end{array}$ & $\begin{array}{r}140 a \\
(16)\end{array}$ & $\begin{array}{r}140 a \\
(16)\end{array}$ & $\begin{array}{r}560 b \\
(58)\end{array}$ & $\begin{array}{r}490 b \\
(35)\end{array}$ & $\begin{array}{r}460 b \\
(63)\end{array}$ \\
\hline 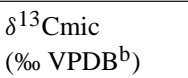 & $\begin{array}{l}-26 a \\
(0.21)\end{array}$ & $\begin{array}{l}-26 a \\
(0.25)\end{array}$ & $\begin{array}{r}-24 a \\
(1.8)\end{array}$ & $\begin{array}{l}-28 b \\
(0.19)\end{array}$ & $\begin{array}{l}-28 b \\
(0.27)\end{array}$ & $\begin{array}{l}19 c \\
(31)\end{array}$ \\
\hline
\end{tabular}

a Below detection limit, meaning below $0.2 \mu \mathrm{g} \mathrm{N} \mathrm{g}^{-1}$ soil dry weight.

b Vienna Pee Dee Belemnite.

$16: 1 \omega 7\left(+330 \% \delta^{13} \mathrm{C}\right)$ and two unsaponifiable, non-esterlinked PLFAs of unknown branching (ubr16:0,+284\%o and $+288 \% \circ \delta^{13} \mathrm{C}$ ). The absolute amount of labelled carbon incorporation into PLFAs is shown in Fig. 4. By far highest values were found for $16: 1 \omega 7\left(0.36 \mathrm{nmol} \mathrm{C} \mathrm{g}^{-1} \mathrm{dw}\right.$ out of $\mathrm{CH}_{4}$ ), followed by $\mathrm{n} 14: 0, \mathrm{n} 16: 016: 1 \omega 5$ and iso $15: 0$ where uptake rates were all more than a factor of 10 lower compared to $16: 1 \omega 7$.

\section{Discussion}

Anaerobic methane oxidation (AOM) has been reported as important methane-consuming process in aquatic habitats, mainly marine ecosystems (Valentine, 2002). For soils the importance of this process is still questionable. Anaerobic conditions in soils might not only be caused by flooding, but also by soil compaction and aggregation. Grasslands used as pastures for cattle overwintering show an increase in anaerobic soil micro-sites caused by animal treading and excrement deposition. Not only the high content of carbon itself, but also the resulting increases in microbial biomass $(72 \%$ higher in cattle highly impacted SI soil compared to unimpacted CO soil) and activity may stimulate soil aggregation (Martens and Frankenberger, 1992). An increase of the mi-

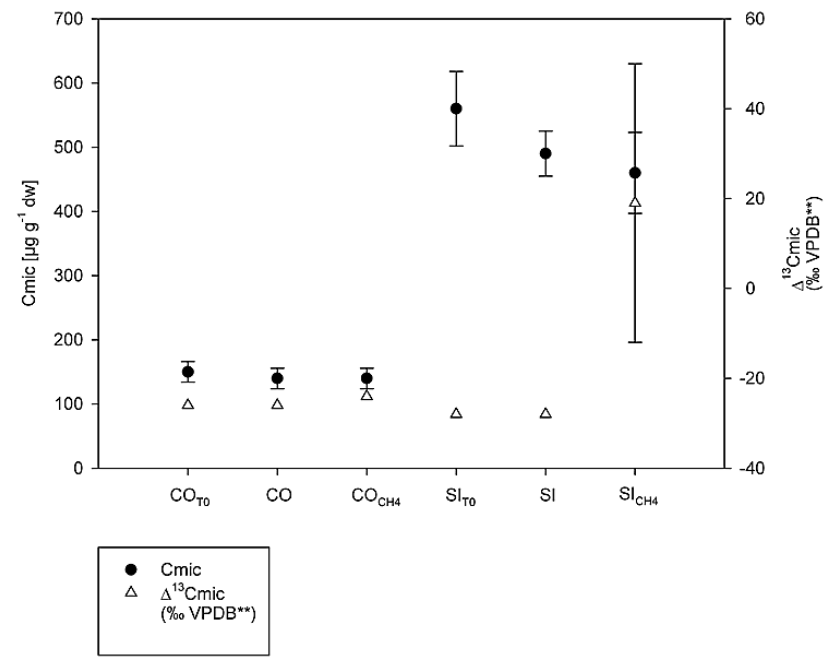

Fig. 2. Microbial biomass (Cmic) and $\delta^{13} \mathrm{C}$ content of microbial biomass $\left(\delta^{13} \mathrm{Cmic}\right)$ before $\left(\mathrm{CO}_{T 0}, \mathrm{SI}_{T 0}\right)$ and after the incubation experiment without $(\mathrm{CO}, \mathrm{SI})$ and with methane $\left(\mathrm{CO}_{\mathrm{CH}_{4}}, \mathrm{SI}_{\mathrm{CH}_{4}}\right)$. Results are presented as means \pm standard deviation $(n=8$ for $\mathrm{SI}_{\mathrm{CH}_{4}}$ and $\mathrm{CO}_{\mathrm{CH}_{4}} ; n=5$ for $\mathrm{SI}_{T 0}, \mathrm{CO}_{T 0}$ and $\mathrm{SI}, \mathrm{CO}$ ). ** Vienna Pee Dee Belemnite.

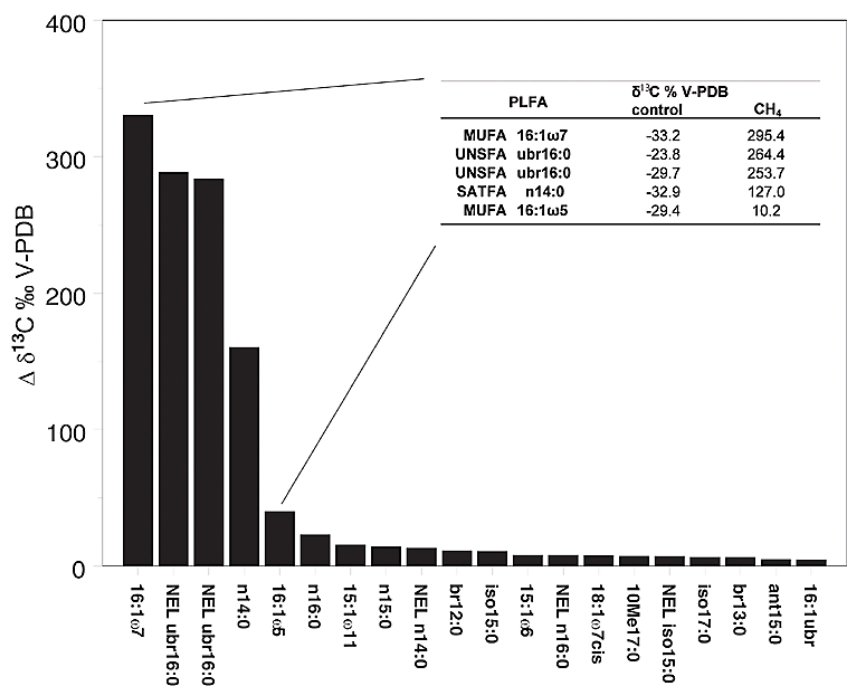

Fig. 3. Ranking of the $\delta^{13} \mathrm{C}$ enrichment in PLFA of $\mathrm{SI}_{\mathrm{CH}_{4}}$ against SI. Values of the five most ${ }^{13} \mathrm{C}$-enriched lipids are given in the inset table.

crobial biomass in SI was confirmed in the study of Elhottová et al. (2012). The latter study also showed different microbial community diversity in SI compared to CO based on extended polar lipid analysis.

Our stable isotope experiment, using ${ }^{13} \mathrm{C}$-labelled methane, allowed us to separate methane production and consumption processes occurring simultaneously. The percentage of $\mathrm{CH}_{4}-\mathrm{C}$ incorporated into $\mathrm{CO}_{2}$ was significantly increased in anaerobically incubated SI soil compared to 


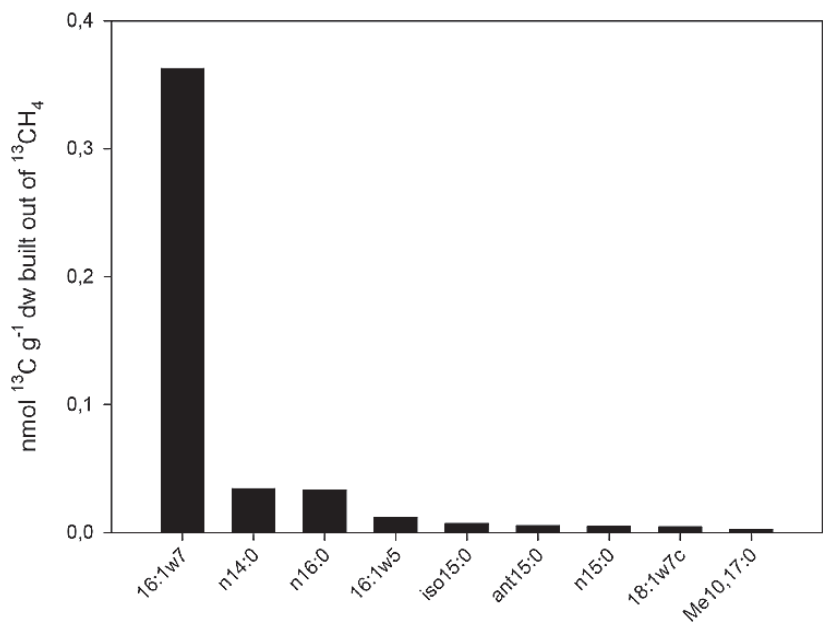

Fig. 4. Ranking of the absolute carbon incorporation from labelled methane into PLFAs of $\mathrm{SI}_{\mathrm{CH}_{4}}$.

CO soil (Fig. 1). This gives clear evidence that AOM occurs in the severely impacted soil under the conditions of the incubation experiment.

No oxygen is supposed to be left in soil pores, as a slurry was used and flushed in addition repeatedly using $\mathrm{O}_{2}$-free nitrogen. However, the possible amount of oxygen in the soil pores was calculated theoretically. At a conservatively estimated dry bulk density of $1.0 \mathrm{~g} \mathrm{~cm}^{-3}$, if all water-free pores were filled with air containing $21 \%$ oxygen, $6.2 \mathrm{mmol}_{2}$ would be available as oxidizing reactant. However, $22.4 \mathrm{mmol} \mathrm{O}_{2}$ are necessary to fully oxidize $500 \mu \mathrm{l}$ of $\mathrm{CH}_{4}$. Thus, oxidation of $73 \%$ of the $500 \mu \mathrm{CH}_{4}$ added cannot be fully explained by aerobic oxidation, even if one assumes that free oxygen was present in soil and that it would not be consumed by oxidation of other substrates. Both of these assumptions are extremely unlikely. Furthermore, decreasing amounts of nitrate and increasing amounts of ammonium (Table 1) indicate absence of nitrification and prevalence of denitrification or other anaerobic processes during incubation, which also confirms that the soil was actually anaerobic.

The presence of other possible electron acceptors for AOM was checked. Sulphate concentrations in SI and CO soils were below the detection limit of $0.13 \mathrm{mg} \mathrm{S} \mathrm{g}^{-1} \mathrm{dw}$. Theoretical calculations showed that at least $126 \mu \mathrm{g} \mathrm{SO}_{4}^{2-} \mathrm{g}^{-1}$ soil would have been necessary to oxidize the added $500 \mu \mathrm{C} \mathrm{CH}_{4}$ (for reaction equation see Scheller et al., 2010). Therefore, it is very likely that sulphate was not the terminal electron acceptor for AOM in the investigated grassland soil. Furthermore, so far AOM coupled to sulphate reduction was only described for marine systems (Hinrichs et al., 1999; Boetius et al., 2000; Strous and Jetten, 2004; Valentine and Reeburgh, 2000).

It was also proposed that $\mathrm{Fe}(\mathrm{III})$ could serve as electron acceptor for AOM in freshwater wetlands (Murase and
Kimura, 1994; Daniel et al., 1999). The reaction is energetically favourable (Smemo and Yavitt, 2011). In the present experiment, iron concentrations ranged between 63 and $83 \mu \mathrm{g}$ $\mathrm{g}^{-1}$ in the different treatments of the SI soil and between 120 and $140 \mu \mathrm{g} \mathrm{g}^{-1}$ in the CO soil. The theoretical amount of $\mathrm{Fe}$ (III) necessary for the oxidation of $500 \mu \mathrm{l}$ methane is ca

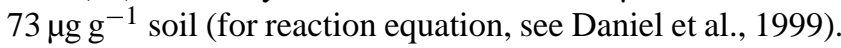
Thus, enough Fe(III) has been in SI soil to serve as terminal electron acceptor for anaerobic oxidation of methane. But only $20 \mu \mathrm{g} \mathrm{g}^{-1} \mathrm{dw}$ were consumed in $\mathrm{SI}_{\mathrm{CH}_{4}}$ during the experiment.

Taking the recent results into account, it is most likely that nitrate/nitrite functioned as electron acceptor for AOM in the SI soil. So far, investigated enrichment cultures preferred nitrite over nitrate. But it remains to be shown whether nitrate can actually be used by "Candidatus Methylomirabilis oxyfera" (Wu et al., 2011). The concentrations of nitrate in the severely impacted soil declined from $23 \mu \mathrm{g} \mathrm{NO}{ }_{3}^{-}$$\mathrm{Ng}^{-1} \mathrm{dw}$ soil to below detection limit after anaerobic conditions were established, but a significant decline was also observed for the control soil and no difference was found between the treatments with and without methane. This might be due to a high activity of denitrifying organisms previously found in the soil SI (Chronáková et al., 2009). The amount of $\mathrm{NO}_{3}^{-}-\mathrm{N}$ necessary to oxidize $500 \mu \mathrm{l}$ of methane would theo-

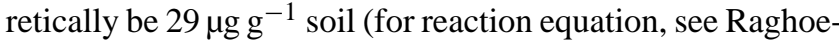
barsing et al., 2006). Taking methodological biases into account, there might have been enough nitrate for the oxidation of the added methane in our incubation experiment.

Significantly increased amounts of ammonium concentrations in the anaerobically incubated SI soils (13 and $12 \mu \mathrm{g} \mathrm{g}^{-1}$ soil) compared to SI soil after aerobic preincubation $\left(1 \mu \mathrm{g} \mathrm{g}^{-1}\right.$ soil) might indicate that dissimilatory nitrate reduction to ammonia (DNRA) occurred. This process takes place under low oxygen conditions like denitrification and might be favoured under high $\mathrm{C} / \mathrm{NO}_{3}^{-}$ratios when the electron acceptor $\left(\mathrm{NO}_{3}^{-}\right)$becomes limiting (Tiedje et al., 1983), as it has been reported for SI. If nitrate/nitrite is the electron acceptor for AOM in the system, there might be a competition for electron acceptors between the two processes. Another possible explanation for the increasing amount of ammonia points towards the mineralization of organic nitrogen and its accumulation resulting from the lack of oxygen (Ghosh and Bhat, 1998).

The finding that the ${ }^{13} \mathrm{C}$-label of methane finally appeared in the microbial biomass (Fig. 2) in soils from SI under anaerobic conditions confirms that $\mathrm{CH}_{4}-\mathrm{C}$ was not only oxidized, but also incorporated by the respective organisms. This provided the opportunity to analyze ${ }^{13} \mathrm{C}$-marked phospholipid fatty acids. Highest relative and absolute label incorporation was detected in PLFA $16: 1 \omega 7$. This indicates that organisms harbouring $16: 1 \omega 7$ are highly active in degrading methane under anaerobic conditions. This assumption is supported by the ratio of $\omega 7$ monounsaturated fatty acids $(\omega 7)$ to 
cyclopropylic fatty acids (cy). The latter named cyclic derivatives of $\omega 7$ MUFAs operate as membrane-stabilizing fatty acids. They are reported to be formed under environmental stress conditions such as starvation (Findlay and Dobbs, 1993; Frostegard et al., 1993). While in the SI soil without methane a $\omega 7$ / cy ratio of 1.7 was observed, it increased to values between 3.1 and 5.3 in the methane-treated SI soil. This indicates that methane was used as nutrient source by these organisms, and hence the nutritional stress decreased.

PLFA 16:1 $1 \omega 7$ was detected as the major PLFA in different Methylococcus and Methylomonas strains belonging to the type I methane-utilizing bacteria by Bowman et al. (1991). But it was also found in strictly and syntrophic anaerobes (Leckie, 2005; Evershed et al., 2006; Zelles, 1997; Henson et al., 1988) and different Gram-negative organisms (Boschker et al., 1998; Holmes et al., 1999; White, 1994). The lack of specific biomarkers for type I methanotrophs, that is to say $16: 1 \omega 8$, as well as type II methanotrophs $(18: 1 \omega 8)$ (Bowman et al., 1991) in the soil of the incubation experiment is an indication that common aerobic methanotrophs of the type I and II cluster are unlikely to explain the observed methane uptake pattern. In contrast, Raghoebarsing et al. (2006) found $16: 1 \omega 7$ also as the highest enriched PLFA in a ${ }^{13} \mathrm{C}$ labelling experiment with an enrichment culture coupling denitrification of nitrate to anaerobic oxidation of methane. In addition, $\mathrm{n} 14: 0, \mathrm{n} 16: 0$ and iso $15: 0$ which incorporated next to $16: 1 \omega 7$ the highest amount of $\mathrm{C}$ out of $\mathrm{CH}_{4}$ in this incubation experiment (Fig. 4), were also found to be ${ }^{13} \mathrm{C}$-enriched in the study of Raghoebarsing et al. (2006). This is an indication of nitrate/nitrite-based AOM in the incubation experiment of this study, maybe by relatives of "Candidatus Methylomirabilis oxyfera".

A high absolute degree of label incorporation was also observed for $16: 1 \omega 5$ which is supposed to be a specific component of type I methanotrophs (Bowman et al., 1991). The unknown branched, unsaponifiable 16: 0 PLFAs are highly ${ }^{13} \mathrm{C}$-enriched, but low abundant. This does not exclude that they play a role in oxidizing methane under anaerobic conditions. These lipids were found in different anaerobe organisms (Ratledge and Wilkinson, 1988; Henson et al., 1988). It cannot be excluded that the incorporation could also be due to the consumption of ${ }^{13} \mathrm{C}-\mathrm{CH}_{4}$-derived ${ }^{13} \mathrm{C}-\mathrm{CO}_{2}$ or feeding on intermediate products. The intensity of the labelling, however, suggests that the lipids in question must be at least partially of methanotrophic origin.

\section{Conclusions}

Results from the present study give clear evidence for an anaerobic activity of methane-oxidizing microorganisms in severely cattle-impacted grassland soil. In a stable isotope experiment using ${ }^{13} \mathrm{C}$-enriched $\mathrm{CH}_{4}$, we were able to detect a high microbial activity utilizing $\mathrm{CH}_{4}$ as carbon source shown by respiration of ${ }^{13} \mathrm{CO}_{2}$. Thus, there is evidence that soil microorganisms have the potential to perform anaerobic oxidation of methane. Moreover, ${ }^{13} \mathrm{C}$-PLFA analyses clearly showed the utilization of $\mathrm{CH}_{4}$ as carbon source mainly by organisms harbouring $16: 1 \omega 7$ PLFAs. These lipids were also found as most ${ }^{13} \mathrm{C}$-enriched fatty acids by Raghoebarsing et al. (2006) after addition of ${ }^{13} \mathrm{CH}_{4}$ to an enrichment culture coupling denitrification of nitrate to anaerobic oxidation of methane. This might be an indication for anaerobic oxidation of methane by relatives of "Candidatus Methylomirabilis oxyfera" in the investigated grassland soil under the conditions of the incubation experiment. However, the used approach in this experiment does not allow differentiating if the metabolized methane is used by the corresponding microbes for an increase in biomass or changed ecophysiological properties (and consequently changed PLFA profiles). Furthermore, it is unclear how much of the applied methane is transformed into $\mathrm{CO}_{2}$ or other metabolites, which are not integrated into the cell-derived carbon. Therefore, a quantitative assessment of the process is not possible based on our data. To overcome this problem, further molecular analyses, including sequencing approaches, are necessary to characterize anaerobic methane oxidizers in different soils.

Acknowledgements. We thank Gudrun Hufnagel for her excellent technical support in measuring ammonium and nitrate concentrations. Financial support was provided by the Czech Science Foundation (project No 526/09/1570).

Edited by: K. Küsel

\section{References}

Boetius, A., Ravenschlag, K., Schubert, C. J., Rickert, D., Widdel, F., Gieseke, A., Amann, R., Jorgensen, B. B., Witte, U., and Pfannkuche, O.: A marine microbial consortium apparently mediating anaerobic oxidation of methane, Nature, 407, 623-626, 2000.

Boschker, H. T. S., Nold, S. C., Wellsbury, P., Bos, D., de Graaf, W., Pel, R., Parkes, R. J., and Cappenberg, T. E.: Direct linking of microbial populations to specific biogeochemical processes by ${ }^{13}$ C-labelling of biomarkers, Nature, 392, 801-805, 1998.

Bowman, J. P., Skerratt, J. H., Nichols, P. D., and Sly, L. I.: Phospholipid fatty acid and lipopolysaccharide fatty acid signature lipids in methane-utilizing bacteria, FEMS Microbiol. Lett., 85, 15-21, 1991.

Chroňáková, A., Radl, V., Cuhel, J., Simek, M., Elhottová, D., Engel, M., and Schloter, M.: Overwintering management on upland pasture causes shifts in an abundance of denitrifying microbial communities, their activity and $\mathrm{N}_{2} \mathrm{O}$-reducing ability, Soil Biol. Biochem., 41, 1132-1138, 2009.

Daniel, R., Warnecke, F., Potekhina, J. S., and Gottschalk, G.: Identification of the syntrophic partners in a coculture coupling anaerobic methanol oxidation to Fe(III) reduction, FEMS Microbiol. Lett., 180, 197-203, 1999.

Deutzmann, J. S. and Schink, B.: Anaerobic oxidation of methane in sediments of Lake Constance, an oligotrophic freshwater lake, Appl. Environ. Microb., 77, 4429-4436, 2011. 
Elhottová, D., Koubová, A., Šimek, M., Cajthaml, T., Jirout, J., Esperschuetz, J., Schloter, M., and Gattinger, A.: Changes in soil microbial communities as affected by intensive cattle husbandry, Appl. Soil Ecol., 58, 56-65, 2012.

Esperschuetz, J., Buegger, F., Winkler, J. B., Munch, J. C., Schloter, M., and Gattinger, A.: Microbial response to exudates in the rhizosphere of young beech trees (Fagus sylvatica L.) after dormancy, Soil Biol. Biochem., 41, 1976-1985, 2009.

Ettwig, K. F., van Alen, T., van de Pas-Schoonen, K. T., Jetten, M. S. M., and Strous, M.: Enrichment and molecular detection of denitrifying methanotrophic bacteria of the NC10 phylum, Appl. Environ. Microb., 75, 3656-3662, 2009.

Ettwig, K. F., Butler, M. K., Le Paslier, D., Pelletier, E., Mangenot, S., Kuypers, M. M. M., Schreiber, F., Dutilh, B. E., Zedelius, J., de Beer, D., Gloerich, J., Wessels, H. J. C. T., van Alen, T., Luesken, F., Wu, M. L., van de Pas-Schoonen, K. T., Op den Camp, H. J. M., Janssen-Megens, E. M., Francoijs, K.-J., Stunnenberg, H., Weissenbach, J., Jetten, M. S. M., and Strous, M.: Nitrite-driven anaerobic methane oxidation by oxygenic bacteria, Nature, 464, 543-548, 2010.

Evershed, R. P., Crossman, Z. M., Bull, I. D., Mottram, H., Dungait, J. A. J., Maxfield, P. J., and Brennand, E. L.: ${ }^{13}$ C-Labelling of lipids to investigate microbial communities in the environment, Curr. Opin. Biotech., 17, 72-82, 2006.

Findlay, R. H. and Dobbs, F. C.: Analysis of microbial lipids to determine biomass and detect the reponse of sedimentary microorganisms to disturbance, in: Aquatic microbial ecology, edited by: Kemp, P. E., Sherr, B. F., Sherr, E. B., and Cole, J. J., Lewies Publishers, Boca Raton, 271-284, 1993.

Frostegard, A., Tunlid, A., and Baath, E.: Phospholipid Fatty Acid composition, biomass, and activity of microbial communities from two soil types experimentally exposed to different heavy metals, Appl. Environ. Microb., 59, 3605-3617, 1993.

Gattinger, A., Ruser, R., Schloter, M., and Munch, J. C.: Microbial community structure varies in different soil zones of a potato field, J. Plant Nutr. Soil Sc., 165, 421-428, 2002.

Ghosh, B. C. and Bhat, R.: Environmental hazards of nitrogen loading in wetland rice fields, Environ. Pollut., 102, 123-126, 1998.

Henson, J. M., McInerney, M. J., Beaty, P. S., Nickels, J., and White, D. C.: Phospholipid fatty acid composition of the syntrophic anaerobic bacterium Syntrophomonas wolfei, Appl. Environ. Microb., 54, 1570-1574, 1988.

Hinrichs, K.-U., Hayes, J. M., Sylva, S. P., Brewer, P. G., and DeLong, E. F.: Methane-consuming archaebacteria in marine sediments, Nature, 398, 802-805, 1999.

Holmes, A. J., Roslev, P., McDonald, I. R., Iversen, N., Henriksen, K., and Murrell, J. C.: Characterization of methanotrophic bacterial populations in soils showing atmospheric methane uptake, Appl. Environ. Microb., 65, 3312-3318, 1999.

Hynšt, J., Šimek, M., Brůček, P., and Petersen, S. O.: High fluxes but different patterns of nitrous oxide and carbon dioxide emissions from soil in a cattle overwintering area, Agr. Ecosyst. Environ., 120, 269-279, 2007.

Islas-Lima, S., Thalasso, F., and Gómez-Hernandez, J.: Evidence of anoxic methane oxidation coupled to denitrification, Water Res., 38, 13-16, 2004.

Jirout, J., Tříska, J., Růžičková, K., and Elhottová, D.: Disturbing impact of outdoor cattle husbandry on community of arbuscular mycorrhizal fungi in upland pasture soil, Commun. Soil Sci.
Plant, 40, 736-745, 2009.

Jörgensen, R. and Brookes, P.: Die Bestimmung der mikrobiellen Biomasse des Bodens mit der Fumigations-ExtraktionsMethode, VDLUFA-Schriftenreihe, Kongreßband 1991, 666671, 1991.

Krummen, M., Hilkert, A. W., Juchelka, D., Duhr, A., Schlüter, H.J., and Pesch, R.: A new concept for isotope ratio monitoring liquid chromatography/mass spectrometry, Rapid Commun. Mass Sp., 18, 2260-2266, 2004.

Leckie, S. E.: Methods of microbial community profiling and their application to forest soils, Forest Ecol. Manag., 220, 88-106, 2005.

Lovley, D. R. and Phillips, E. J. P.: Rapid assay for microbially reducible ferric iron in aquatic sediments, Appl. Environ. Microb., 53, 1536-1540, 1987.

Mancinelli, R. L.: The Regulation of methane oxidation in soil, Annu. Rev. Microbiol., 49, 581-605, 1995.

Martens, D. A. and Frankenberger, W. T.: Modification of infiltration rates in an organic-amended irrigation soil, Agron. J., 84, 707-717, 1992.

Marx, M., Buegger, F., Gattinger, A., Zsolnay, Á., and Munch, J. C.: Determination of the fate of ${ }^{13} \mathrm{C}$ labelled maize and wheat exudates in an agricultural soil during a short-term incubation, Eur. J. Soil Sci., 58, 1175-1185, 2007.

Menneer, J. C., Ledgard, S., McLay, C., and Silvester, W.: Animal treading stimulates denitrification in soil under pasture, Soil Biol. Biochem., 37, 1625-1629, 2005.

Murase, J. and Kimura, M.: Methane production and its fate in paddy fields: VII. Electron acceptors responsible for anaerobic methane oxidation, Soil Sci. Plant Nutr., 40, 647-654, 1994.

Pozdnyakov, L., Stepanov, A., and Manucharova, N.: Anaerobic methane oxidation in soils and water ecosystems, Moscow Univ. Soil Sci. Bull., 66, 24-31, 2011.

Radl, V., Gattinger, A., Chronakova, A., Nemcova, A., Cuhel, J., Simek, M., Munch, J. C., Schloter, M., and Elhottova, D.: Effects of cattle husbandry on abundance and activity of methanogenic archaea in upland soils, ISME J., 1, 443-452, 2007.

Raghoebarsing, A. A., Pol, A., van de Pas-Schoonen, K. T., Smolders, A. J. P., Ettwig, K. F., Rijpstra, W. I. C., Schouten, S., Damste, J. S. S., Op den Camp, H. J. M., Jetten, M. S. M., and Strous, M.: A microbial consortium couples anaerobic methane oxidation to denitrification, Nature, 440, 918-921, 2006.

Rasigraf, O., Vogt, C., Richnow, H.-H., Jetten, M. S. M., and Ettwig, K. F.: Carbon and hydrogen isotope fractionation during nitrite-dependent anaerobic methane oxidation by Methylomirabilis oxyfera, Geochim. Cosmochim. Ac., 89, 256-264, 2012.

Ratledge, C. and Wilkinson, S. (Eds.): Mirobial lipids, Academic Press, London, 1988.

Scheller, S., Goenrich, M., Boecher, R., Thauer, R. K., and Jaun, B.: The key nickel enzyme of methanogenesis catalyses the anaerobic oxidation of methane, Nature, 465, 606-608, 2010.

Shima, S. and Thauer, R. K.: Methyl-coenzyme M reductase and the anaerobic oxidation of methane in methanotrophic Archaea, Curr. Opin. Microbiol., 8, 643-648, 2005.

Šimek, M., Brůček, P., Hynšt, J., Uhlîrová, E., and Petersen, S. O.: Effects of excretal returns and soil compaction on nitrous oxide emissions from a cattle overwintering area, Agr. Ecosyst. Environ., 112, 186-191, 2006. 
Smemo, K. A. and Yavitt, J. B.: Anaerobic oxidation of methane: an underappreciated aspect of methane cycling in peatland ecosystems?, Biogeosciences, 8, 779-793, doi:10.5194/bg-8-779-2011, 2011.

Smith, R. L., Howes, B. L., and Garabedian, S. P.: In situ measurement of methane oxidation in groundwater by using naturalgradient tracer tests, Appl. Environ. Microb., 57, 1997-2004, 1991.

Strous, M. and Jetten, M. S. M.: Anaerobic oxidation of methane and ammonium, Annu. Rev. Microbiol., 58, 99-117, 2004.

Thauer, R. K. and Shima, S.: Methane as fuel for anaerobic microorganisms, Ann. NY Acad. Sci., 1125, 158-170, 2008.

Tiedje, J. M., Sexstone, A. J., Myrold, D. D., and Robinson, J. A.: Denitrification: ecological niches, competition and survival, Anton. Leeuw., 48, 569-583, 1983.

Valentine, D.: Biogeochemistry and microbial ecology of methane oxidation in anoxic environments: a review, Anton. Leeuw., 81, 271-282, 2002.

Valentine, D. L. and Reeburgh, W. S.: New perspectives on anaerobic methane oxidation, Environ. Microbiol., 2, 477-484, 2000.
Vance, E. D., Brookes, P. C., and Jenkinson, D. S.: An extraction method for measuring soil microbial biomass C, Soil Biol. Biochem., 19, 703-707, 1987.

White, D. C.: Is there anything else you need to understand about the microbiota that cannot be derived from analysis of nucleic acids?, Microb. Ecol., 28, 163-166, 1994.

Wu, M. L., Ettwig, K. F., Jetten, M. S. M., Strous, M., Keltjens, J. T., and van Niftrik, L.: A new intra-aerobic metabolism in the nitrite-dependent anaerobic methane-oxidizing bacterium Candidatus "Methylomirabilis oxyfera", Biochem. Soc. T., 39, 243248, 2011.

Zelles, L.: Phospholipid fatty acid profiles in selected members of soil microbial communities, Chemosphere, 35, 275-294, 1997.

Zelles, L.: Fatty acid patterns of phospholipids and lipopolysaccharides in the characterisation of microbial communities in soil: a review, Biol. Fert. Soils, 29, 111-129, 1999.

Zelles, L., Rackwitz, R., Bai, Q., Beck, T., and Beese, F.: Discrimination of microbial diversity by fatty acid profiles of phospholipids and lipopolysaccharides in differently cultivated soils, Plant Soil, 170, 115-122, 1995. 